\title{
IbM KELOMPOK USAHA PEMBESARAN AYAM BURAS DI DESA PENGARON KECAMATAN PENGARON KABUPATEN BANJAR KALIMANTAN SELATAN
}

\author{
Siti Erlina dan Ilhamiyah \\ Fakultas Pertanian, Universitas Islam Kalimantan $\mathrm{Mb}$ \\ Email : sitierlina@yahoo.com
}

\begin{abstract}
The productivity of Chicken in two groups of partners (Kindai Limpar and Harapan Masa) in Pengaron Sub-district, Banjar Regency, South Borneo, is still low. This is due to the lack of knowledge about the management of breeders of good and correct Chicken care and the inability of farmers to buy a tool for the beak (debeaker), because the price is very expensive and only outside of South Borneo. In addition, knowledge of effective and efficient marketing strategies is still lacking. Therefore, Science and Technology Program for the Community is very necessary to overcome these problems. The target audience of this program is a society that has not been economically productive but has a strong desire to become an entrepreneur. Outcome targets are services and Technology / tools / products / goods. The method used is counseling and demonstration. Both groups of Partners get knowledge through counseling and technology transfer in the form of cutting tool part (debeaker) in a special modification, simple and cheap (modified debeaker from the team proposer). In this counseling activity breeders are given maintenance ways to start seedling, seed selection, cage, feeding, drinking, beak cutting techniques, pest control and chicken livestock disease (vaccine feeding technique), maintenance techniques of Chicken Buras start zero days until with three weeks and maintenance techniques of Chicken Buras age three weeks up to the age of eight weeks. In addition, the two partner groups are assisted by the provision of partial modification tools (debeaker) of the team as well as informed on how to use the tool and partners are also given knowledge about the marketing strategy of effective and efficient domestic poultry. Based on the results of the activities of IbM it can be seen that the participants / partners IbM very interested and enthusiastic with the activities of this IbM. This activity can open the insight of breeders, improve knowledge and skills of breeders in breeding chickens males with better technology implementation and correct, so it can overcome the problems faced by farmers so far and will ultimately increase the income and welfare breeders
\end{abstract}

Keywords : Business Chicken, Debeaker, Pengaron

\section{PENDAHULUAN}

Pendapatan perkapita masyarakat serta pendidikan dan ilmu pengetahuan yang meningkat berdampak pada meningkatnya taraf hidup masyarakat. Akibatnya terjadi perubahan menu makanan. Awalnya konsumsi masyarakat cenderung pada makanan yang mengandung karbohidrat tinggi, sekarang, tingginya konsumsi karbohidrat tergantikan dengan menu berprotein hewan tinggi yaitu telur dan 
daging. Di sisi lain tingginya kebutuhan protein hewani belum mampu dipenuhi karena sebagian besar peternakan di indonesia merupakan peternakan rakyat yang menggunakan teknologi tradisional, meskipun populasi ternak dari tahun ke tahun terus meningkat (Susilorini dkk, 2009). Untuk mendapatkan produksi peternakan yang optimal, maka perlu dilakukan optimalisasi produksi peternakan. Optimalisasi produksi peternakan bisa dicapai jika didukung oleh tiga faktor besar yaitu: pakan, manajemen atau tatalaksana dan pemuliaan (breeding) ternak. Faktor pakan sangat terkait dengan cara pemberiannya yaitu harus sesuai dengan kebutuhan ternak untuk hidup pokok, pertumbuhan dan produksi semaksimal mungkin dengan biaya yang ekonomis. Tatalaksana merupakan cara-cara pemeliharaan sehari-hari yaitu membersihkan ternak, perkandangan, pencegahan dan pengobatan penyakit serta penanganan perkawinan yang teratur dan tepat waktu. Pemuliaan (breeding) ternak adalah melakukan seleksi (pemilihan bibit) dan sistem perkawinan sehingga diperoleh bibit yang unggul. Apabila ketiga faktor tersebut dapat dijalankan dengan baik, maka akan diperoleh produksi ternak yang sesuai dengan harapan dan potensi genetiknya (Indarto,dkk, 2006).

Menurut Rasyaf (1992), Dari ketiga factor tersebut tatalaksana pemeliharaan ternak memegang peranan yang paling besar dalam keberhasilan usaha peternakan yaitu sebesar 50\%, adapun pakan dan bibit masing-masing mempunyai peranan 30 dan $20 \%$. Itulah sebabnya pengetahuan tentang tatalaksana pemeliharaan sangat penting dikuasai, tidak terkecuali untuk pemeliharaan ayam buras.

Ayam buras yang dipelihara secara intensif dengan tatalaksana yang baik mempunyai prospek yang baik untuk dikembangkan sebagai penghasil daging, bahkan daging yang dihasilkan mempunyai kandungan lemak abdominalnya relatif rendah jika dibandingkan dengan ayam pedaging pada umumnya. Oleh karena itu tatalaksana pemeliharaan ayam buras yang baik dan teratur sangat penting di kuasai, dilakukan dan diterapkan, sehingga pemeliharaan ayam petelur tersebut dapat memberikan nilai ekonomis yang potensial untuk meningkatkan kesejahteraan peternak. 
Salah satu alternatif upaya peningkatan produktivitas ayam buras guna meningkatkan pendapatan petani peternak adalah dengan melakukan tatalaksana pemeliharaan ayam buras yang baik dan benar, akan tetapi masih banyak petani peternak yang masih memelihara ternaknya secara tradisional. Sebagai salah satu contoh Peternak tidak pernah melakukan potong paruh pada ayam buras, padahal ayam buras mempunyai sifat kanibalisme, sehingga jika tidak dilakukan potong paruh maka akan mengakibatkan tingginya angka mortalitas pada ayam buras tersebut yang pada akhirnya akan merugikan peternak. Rendahnya produktivitas dan tingginya angka mortalitas pada ayam buras tersebut disebabkan karena kurangnya pengetahuan peternak tentang tatalaksana pemeliharan ayam buras yang baik dan benar serta ketidakmampuan peternak untuk membeli alat potong paruh (debeaker), karena harganya sangat mahal dan hanya ada di luar Kalimantan Selatan. Oleh karena itu program Ipteks bagi Masyarakat ini sangat diperlukan untuk mengatasi permasalahan tersebut.

\section{TUJUAN DAN MANFAAT}

\section{Tujuan}

Tujuan kegiatan Ipteks bagi Masyarakat ini adalah:

a. Memberikan informasi bagi masyarakat setempat tentang Pemeliharaan dan Potong Paruh pada Ayam buras

b. Membantu masyarakat ini dalam Pemeliharaan dan Potong Paruh pada Ayam buras sehingga dapat meningkatkan pendapatannya.

\section{Manfaat}

Hasil dari Kegiatan ini diharapkan dapat bermanfaat :

- Bagi masyarakat

Bertambahnya pengertian dan pengetahuan tentang Tatalaksana Pemeliharaan dan Potong Paruh pada Ayam buras sehingga dapat menambah pendapatan keluarga.

- Bagi pelaksana kegiatan

Memperoleh kesempatan untuk mengamalkan ilmu bagi kepentingan masyarakat sebagai bentuk nyata dari pelaksanaan dharma ketiga dari Tridharma Perguruan Tinggi.

- Bagi Pemerintah

Membantu dalam rangka penyuluhan dan demonstrasi 
tentang Pemeliharaan dan Potong Paruh pada Ayam buras.

\section{METODE}

\section{Target Kegiatan}

Anggota khalayak sasaran yang dilibatkan dalam kegiatan ini adalah :

a. Masyarakat desa setempat sebagai sasaran kegiatan

b. Tokoh masyarakat sebagai penggerak masyarakat yang diharapkan mampu mengajak masyarakat untuk melaksanakan Tatalaksana Pemeliharaan dan Potong Paruh pada Ayam buras

c. Penyuluh Pertanian Lapangan sebagai mediator penyaluran teknologi modern

\section{Luaran Kegiatan}

Luaran kegiatan Ipteks bagi

Masyarakat ini adalah:

- Jasa berupa penyuluhan dan demonstrasi tentang tatalaksana pemeliharaan dan potong paruh pada ayam buras.

- Teknologi tepat guna/alat yaitu dengan mentransfer teknologi berupa alat potong paruh ('debeaker' hasil modifikasi tim pelaksana IbM).

Metode Pelaksanaan
Metode yang digunakan dalam kegiatan ini adalah:

1. Penyuluhan tentang tatalaksana pemeliharaan ayam buras terutama cara potong paruh dengan penerapan teknologi yang baik dan benar

2. Demonstrasi Pemeliharaan dan Potong Paruh pada Ayam buras.

3. Mentransfer teknologi berupa alat potong paruh (debeaker) yang di modifikasi khusus, sederhana dan murah (debeaker hasil modifikasi dari tim pelaksana)

4. Kedua kelompok baik ketua beserta anggotanya mengikuti pembelajaran Teori dengan rasio pertemuan sebesar $20 \%$ dan praktik dengan rasio pertemuan 80 $\%$.

\section{Materi Kegiatan}

Materi kegiatan yang di berikan kepada kelompok mitra adalah :

a. Penyuluhan tentang:

- Tatalaksana pemeliharaan ayam buras mulai bibit sampai produksi.

- Potong Paruh pada ayam buras

- Manajemen Pemasaran Ayam buras

b. Perkenalan alat potong paruh (Debeaker dan Debeaker 
modifikasi) dan demonstrasi penggunaan alat tersebut

c. Demonstrasi pemeliharaan Ayam buras

d. Evaluasi, berupa tanya jawab/diskusi dengan kelompok mitra untuk memecahkan potret permasalahan lain yang terekam yang di hadapi peternak.

\section{HASIL DAN PEMBAHASAN}

\section{Analisis Evaluasi dan Hasil}

Berdasarkan hasil pengamatan terhadap pelaksanaan penyuluhan yang dilakukan tim pelaksana IbM dapat diketahui bahwa peserta/mitra IbM sangat tertarik dan antusias dengan adanya kegiatan IbM ini, hal ini terlihat dari banyaknya permasalahan atau pertanyaan yang diajukan dan keinginan yang besar untuk memelihara/beternak kembali pasca kegiatan ini.

Dari hasil tanya jawab dapat diketahui bahwa kelompok mitra tidak mengetahui tentang alat potong paruh (debeaker) sehingga mereka belum pernah melakukan potong paruh pada ternaknya. Kelompok mitra sangat antusias ketika Tim pelaksana IbM memperkenalkan alat potong paruh. Alat tersebut memang mempunyai kelebihan dan kelemahan masingmasing. Namun pada prinsifnya mempunyai Tujuan dan manfaat yang sama yaitu:

1. Mengefisiensikan penggunaan pakan. Ayam yang dipotong paruhnya tidak akan pilih-pilih makanan sedang pada ayam yang tidak dipotong paruhnya akan lebih memilih jenis makanan yang berbutir (crumble dan pellet) daripada jenis tepung (mash). Sehingga kebanyakan makanan yang tersisa adalah jenis tepung.

2. Mengeliminasi sifat kanibal, baik kanibal antar ayam atau kanibal makan telurnya. Sifat kanibal antar ayam dapat dicegah dengan cara isolasi atau memisahkannya. Sedangkan kanibal memakan telur merupakan sifat genetik yang akan muncul apabila sifat fenotif mendukung seperti kepadatan kandang yang terlalu tinggi, keterlambatan pemberian pakan, ventilasi kurang, dan pakan yang kekurangan $\mathrm{NaCl}$ dan lain sebagainya.

3. Meningkatkan pertumbuhan dan produksi telur, dengan efisiensi penggunaan pakan maka laju 
pertumbuhan diharapkan meningkat pula.

Di samping memberikan manfaat, potong paruh juga mempunyai sisi negatif seperti :

- Menimbulkan stress, karena setelah beberapa waktu pelaksanaan potong paruh unggas akan mengeluarkan darah walaupun jumlahnya kecil dan ini menghalanginya untuk makan dan aktifitas lainnya.

- Meningkatkan mortalitas, karena unggas yang stress tidak menutup kemungkinan akan sampai menyebabkan kematian kalau penanganan pasca potong paruh kurang mendapat perhatian.

- Walaupun potong paruh mempunyai sisi negatif, akan tetapi kelompok mitra tidak merasa khawatir lagi, karena mereka telah membuktikan sendiri bahwa ayam yang dipotong paruhnya akan menampilkan produksinya lebih baik daripada ayam yang tidak dipotong paruhnya.

\section{KESIMPULAN DAN SARAN}

\section{Kesimpulan}

Berdasarkan hasil kegiatan yang telah dilaksanakan dapat disimpulkan bahwa:

1. Pengetahuan mitra menjadi meningkat, mitra mengetahui bagaimana tatalaksana pemeliharan usaha Ayam Buras yang baik dan benar

2. Mitra dapat menggunakan alat potong paruh (debeaker)

3. Mitra mengetahui tentang strategi pemasaran ayam buras yang efektif dan efisien

\section{Saran}

Masyarakat kecamatan Pengaron Khususnya dan masyarakat di Kalimantan Selatan umumnya agar dapat terus mengembangkan usaha peternakannya untuk meningkatkan pendapatan keluarga.

\section{REFERENSI}

Direktorat Jenderal Bina

Produksi Ternak 2003.

Statistik Peternakan Departemen

Pertanian Republik Indonesia. Jakarta

Indarto, P.,A.Zakaria, Muharlien, E.Sudjarwo dan Wiharto. 2006. Manajemen Ternak Unggas. Fakultas Peternakan Universitas Brawijaya. Malang. 
Volume 3 Nomor 2, April 2018

Murtidjo, B.A. 1992. Mengelola

Ayam Buras.

Kanisius.

Yogyakarta

Nurjana, G; Ruwendra,R ;Zaynanto,S; Suprapto, H; Dedy,K; Furqon,O; Indra,P; Mangunkusuma dan Nuriyanto, R. 1983. Pedoman Praktis Pemeliharaan Ayam Petelur dan Pedaging/Pejantan. PT.Pyridam. Jakarta

Rasyaf, M., 1992. Memelihara Ayam Kampung. Penebar Swadaya. Jakarta
Rasyaf, $\quad$ M., 1992.

Memelihara Ayam Buras.

Kanisius. Yogyakarta.

Supriyatna,E ; U Atmomarsono dan R.K. Sudjana. 2005. Ilmu

Dasar Ternak Unggas. Penebar Swadaya. Jakarta.

Susilorini,T.E; M.E.Sawitri dan Muharlien. 2009. Budidaya 22 Ternak Potensial. Penebar Swadaya. Jakarta 
Volume 3 Nomor 2, April 2018 